Research article

\title{
OBSERVATION OF HERMANN'S TORTOISE (TESTUDO HERMANNI) CLUTCHING WITHOUT THE PRESENCE OF MALES AND EGGSHELL MORTALITY ON A LARGE TORTOISE FARM IN SLOVENIA OVER A THREE-YEAR PERIOD
}

\author{
STVARNIK Mateja ${ }^{1}$, LINDTNER-KNIFIC Renata ${ }^{5}$ ŠTOKAR Žan ${ }^{2}$, \\ GREGURIĆ GRAČNER Gordana ${ }^{3}$, MIĆUNOVIĆ Jasna ${ }^{4}$, DOVČ Alenka ${ }^{5 *}$ \\ ${ }^{1}$ University of Ljubljana, Veterinary Faculty, Clinic for Reproduction and Large Animals, Gerbičeva 60, \\ 1000 Ljubljana, Slovenia; ${ }^{2}$ University of Ljubljana, Veterinary Faculty, Gerbičeva 60, 1000 Ljubljana, \\ Slovenia (student); ${ }^{3}$ University of Zagreb, Faculty of Veterinary Medicine, Department of Animal \\ Hygiene, Behaviour and Welfare, Heinzelova 55, 10000 Zagreb, Croatia; ${ }^{4}$ University of Ljubljana, \\ Veterinary Faculty, Institute of Microbiology and Parasitology, Gerbičeva 60, 1000 Ljubljana, Slovenia; \\ ${ }^{5}$ University of Ljubljana, Veterinary Faculty, Institute for Poultry, Birds, Small Animals and Reptiles, \\ Gerbičeva 60, 1000 Ljubljana, Slovenia
}

(Received 14 November 2019, Accepted 06 July 2020)

The aim of this study was to determine the percentage of hatched and fertilized eggs in female Hermann's tortoises before and after the removal of males after breeding.

A breeding group of Testudo hermanni boettgeri with 50 females and 12 males was included in the study. In the first year, all adults were together in the same habitat until reproductive activity was observed. After the end of May, the males and females were separated for the next two active seasons. The number of eggs and number of second clutches decreased gradually. In the first year, $76.0 \%$ of females laid eggs; in the second year, $24.0 \%$; and in the third year, only $8.0 \%$. Second clutches were observed in ten females $(26.3 \%)$ in the first year, while in the next two years, one female had a second clutch. There was a small but significant correlation between the weight of a single tortoise and the number of eggs laid but no significant correlation between the weight of the tortoise and its average egg weight. The weight (15.1-16.8 g), length (33.9$36.1 \mathrm{~mm})$ and width of each egg $(27.5-28.0 \mathrm{~mm})$ was measured.

During the laying season, the eggs were put into incubators. The incubation length varied from 52 to 70 days. After the end of incubation, eggshell mortality and its causes (19.3-52.5\%) were examined. In the first year, the viability rate of the incubated eggs was $80.7 \%$; in the second year, $80.5 \%$; and in the third year, $47.8 \%$. Among the unhatched eggs in the first year, $62.5 \%$ were unfertilized, $53.1 \%$ were infected, $28.1 \%$ were dehydrated and $21.9 \%$ were found in various stages of embryonic development.

Key words: breeding; reproduction; incubation; eggshell mortality; Testudo hermanni

\footnotetext{
*Corresponding author: e-mail: alenka.dovc@vf.uni-lj.si
} 


\section{INTRODUCTION}

Hermann's tortoise (Testudo hermanni) ( $\mathrm{TH}$ ) is a medium-sized terrestrial species that can be found in nature in the European Mediterranean area. Currently, two subspecies have been distinguished: Testudo hermanni hermanni (THH) in Western Europe and Testudo hermanni boettgeri (THB) in Eastern Europe [1]. Scientists disagree about the existence of a third subspecies, Testudo hermanni hercegovinensis [2]. Hermann's tortoise is covered by Regulation (EC) No. 338/97 and listed in Annex A [3]. The main threats to Hermann's tortoises are loss of habitat, pollution, urbanisation, tourism, the pet trade, road mortality, and potential disease impacts from released pet tortoises [4,5].

Chelonian species require years or decades to reach sexual maturity. Gestation is quite remarkable with regard to the time period from fertilization to laying. It depends on different environmental and nesting conditions. Females can lay fertile eggs up to four years after mating, although fertility decreases significantly after each season [6].

In nature, sexual activity of TH occurs from March to October and is most frequent in August and September [7]. The nesting season is in May and June as there is no sexual activity. The minimum plastron size of sexually active males is approximately $120 \mathrm{~mm}$, and that for females is $130 \mathrm{~mm}$. Tortoises are promiscuous in their mating habits, and there is no evidence of mate selection in relation to size [8]. Galeotti et al. (2007) found that both sexes correctly discriminated between odours of their own species and other species, but only males could distinguish the sex and sexual maturity of potential mates by olfactory cues [9]. Clutch site selection is correlated with ground temperature, and nesting itself mainly occurs in the early evening before dark, when the ground temperature characteristics are most indicative of a specific site's relative temperature [8].

The size and shape of eggs can vary within species and even within individual clutches. TH eggs are white, hard-shelled and almost elliptical. In THH, the maximum number of eggs in a clutch is seven, and in THB, it is nine; the mean clutch sizes are 3.3 and 4.3 eggs, respectively. TH most frequently lay one to two and rarely three clutches per year [1].

Temperature-dependent sex determination is characteristic of TH [10]. Hours of embryonic development above the threshold temperature during the sensitive period are decisive for sex determination. The threshold temperature is the temperature for a sex ratio of 1:1 [11].

Normal embryonic development has been described in detail for some species of turtles, such as the Chinese softshelled turtle (Pelodiscus sinensis) [12] and Olive ridley sea turtle (Lepidochelys olivacea) [13]. The reason for lower viability rates in incubated eggs are the presence of unfertilized eggs or embryonic deaths during incubation. Moreover, eggs can be infected, mainly with different bacterial and mycological pathogens or exposed to various stages of dehydration, including mummification. Dead and alive individuals with deformities and twins can also be observed [14]. 
The aim of this study was to determine the percentages of hatching and fertilization in eggs in Hermann's tortoise females during a three-year period with the absence of males.

\section{MATERIAL AND METHODS}

\section{Parent tortoises}

Research was performed on a large tortoise farm in Slovenia [3]. According to the national legislation, the breeder had obtained a breeding permit for breeding Hermann's tortoises (THB).

Fifty females and twelve males, which were from ten to twenty-two years old, were included in the breeding group. They were kept in the same enclosure, which was $3 \mathrm{x}$ $20 \mathrm{~m}^{2}$ in size. During the first year of our study, all adults stayed together in the same habitat until reproductive activity was observed. During the breeding season, they were allowed to mate and move freely. After the end of May, the males were relocated into the adjacent enclosure.

For the next two years, males and females were physically separated. Around the enclosure of the female group included in the study, there were other enclosures that were separated by wire fences as barriers. In these other enclosures, adult breeding tortoises of different genders were located, and they were used as a control group in our study. Fresh food was fed to the animals throughout the study as well as beforehand. The tortoises hibernated separately, with each group in their own enclosure, from the end of October to the mid of April.

The fifty females were followed individually; all tortoises were microchipped in 2012 [15]. Prior to the study, the tortoises were weighted. The heaviest tortoise weighed $1281 \mathrm{~g}$, and the lightest tortoise weighed $678 \mathrm{~g}$.

\section{Egg collection and artificial incubation}

The tortoises were observed several times during the day. The spot where the tortoise dug a hole and laid eggs was marked with a stick. After the eggs were buried, we dug them out, numbered them, weighed them and measured their length and width. During the laying season from June to the beginning of July, the eggs were put into hatcheries within less than six hours. All eggs received the same handling, transport, and artificial incubation conditions.

The hatching temperature varied from 31 to $32^{\circ} \mathrm{C}$. The eggs were placed on a substrate (vermiculite), which was occasionally moistened. The relative humidity was approximately $80 \%$. 


\section{Hermann's tortoise eggshell mortality and additional examinations}

After incubation, the fertilization of all unhatched eggs was examined, and the causes of embryonic mortality were determined. Samples were collected during the examination of the remaining eggs and sent for bacteriological and mycological testing.

Samples were inoculated on blood agar (Blood Agar Base No. 2, Oxoid, Hampshire, UK; supplemented with 5\% sheep blood), URI Select agar (Bio-Rad Laboratories) and Sabouraud dextrose agar (Oxoid Microbiology Products, Basingstoke, UK) with chloramphenicol $(100 \mathrm{mg} / \mathrm{l})$ and incubated at $30^{\circ} \mathrm{C}$ for $24-96$ hours. The bacteriological characterization was based on colony morphology, Gram staining and biochemical reactions: oxidation-fermentation $(\mathrm{O}-\mathrm{F})$, indole, oxidase and catalase.

\section{Statistical analysis}

Spearman's correlations between the weight of a single tortoise and the number of eggs laid and the correlations between the weight of a tortoise and its average egg weight were calculated.

\section{RESULTS}

\section{Parent tortoises}

During the laying season, hatching of eggs from fifty Hermann's tortoises was observed during the three years. The number and percentage of eggs from each female were monitored for each clutch. After the end of the first year, males were removed, and no mating occurred. The results are presented in Table 1.

The overview of female tortoises showed that two of the egg-laying tortoises laid eggs every year, nine of them the first two years, and one tortoise laid eggs in the first and third years. None of the tortoises clutched twice in any three-year period. Only two tortoises clutched five times in three years, and these individuals laid 20 and 15 eggs. The heaviest tortoise (1281 g; 22 years old) laid seven eggs in one nest.

In the first clutch in the first year, 4.3 more eggs were found than in the second one. In the second and third years, a second clutch was observed in only one tortoise in each year.

Every hatched egg was tracked, and the weight, length and width were measured. The results of the egg measurements are presented in Table 2.

A comparison between the weight of the tortoise and the number of its eggs is shown in Graph 1, and a comparison between the weight of every tortoise and the weight of its eggs is shown in Graph 2. The results are shown only for the first year. 
Table 1. The number and percentage of females that laid eggs and the number and percentage of eggs per clutch

\begin{tabular}{|c|c|c|c|c|c|c|c|}
\hline \multicolumn{8}{|c|}{ First year } \\
\hline \multicolumn{3}{|c|}{ First clutch } & \multicolumn{3}{|c|}{ Second clutch } & \multicolumn{2}{|c|}{$\begin{array}{l}\text { Both clutches together } \\
\text { from } 7 \text {. June to } 7 \text { July }\end{array}$} \\
\hline $\begin{array}{c}\text { No. of } \\
\text { females } \\
\text { laying eggs } \\
(\%)\end{array}$ & $\begin{array}{l}\text { No. of } \\
\text { eggs in the } \\
1^{\text {st }} \text { clutch } \\
(\%)\end{array}$ & $\begin{array}{l}\text { Average } \\
\text { no. of } \\
\text { eggs in the } \\
1^{\text {st }} \text { clutch } \\
\text { (min-max) }\end{array}$ & $\begin{array}{l}\text { No. of } \\
\text { females } \\
\text { in the } 2^{\text {nd }} \\
\text { clutch } \\
(\%)\end{array}$ & $\begin{array}{l}\text { No. of eggs } \\
\text { in the } 2^{\text {nd }} \\
\text { clutch }(\%)\end{array}$ & $\begin{array}{l}\text { Average } \\
\text { no. of } \\
\text { eggs in } \\
\text { the } 2^{\text {nd }} \\
\text { clutch } \\
\text { (min-max) }\end{array}$ & $\begin{array}{l}\text { No. of eggs } \\
\text { in both } \\
\text { clutches } \\
(\%)\end{array}$ & $\begin{array}{l}\text { Average } \\
\text { no. of eggs } \\
\text { in both } \\
\text { clutches } \\
\text { (min-max) }\end{array}$ \\
\hline $38(100.0)$ & $135(81.3)$ & $3.6(1-7)$ & $10(26.3)$ & $31(18.7)$ & $3.1(1-6)$ & $166(100.0)$ & $3.5(1-7)$ \\
\hline \multicolumn{8}{|c|}{ Second year } \\
\hline \multicolumn{3}{|c|}{ First clutch } & \multicolumn{3}{|c|}{ Second clutch } & \multicolumn{2}{|c|}{$\begin{array}{l}\text { Both clutches together } \\
\text { from } 6 \text {. June to } 28 \text { June }\end{array}$} \\
\hline $\begin{array}{c}\text { No. of } \\
\text { females } \\
\text { laying eggs } \\
(\%)\end{array}$ & $\begin{array}{l}\text { No. of } \\
\text { eggs in the } \\
1^{\text {st }} \text { clutch } \\
(\%)\end{array}$ & $\begin{array}{l}\text { Average } \\
\text { no. of } \\
\text { eggs in the } \\
1^{\text {st }} \text { clutch } \\
\text { (min-max) }\end{array}$ & $\begin{array}{l}\text { No. of } \\
\text { females } \\
\text { in the } 2^{\text {nd }} \\
\text { clutch } \\
(\%)\end{array}$ & $\begin{array}{l}\text { No. of eggs } \\
\text { in the } 2^{\text {nd }} \\
\text { clutch }(\%)\end{array}$ & $\begin{array}{l}\text { Average } \\
\text { no. of } \\
\text { eggs in } \\
\text { the } 2^{\text {nd }} \\
\text { clutch } \\
\text { (min-max) }\end{array}$ & $\begin{array}{l}\text { No. of eggs } \\
\text { in both } \\
\text { clutches } \\
\text { according } \\
\text { to the first } \\
\text { year }(\%)\end{array}$ & $\begin{array}{l}\text { Average } \\
\text { no. of eggs } \\
\text { in both } \\
\text { clutches } \\
\text { (min-max) }\end{array}$ \\
\hline $12(100.0)$ & 39 (95.1) & $3.3(2-4)$ & $1(8.3)$ & $2(4.9)$ & $2.0(2)$ & $41(24.7)$ & $3.2(2-4)$ \\
\hline \multicolumn{8}{|c|}{ Third year } \\
\hline \multicolumn{3}{|c|}{ First clutch } & \multicolumn{3}{|c|}{ Second clutch } & \multicolumn{2}{|c|}{$\begin{array}{l}\text { Both clutches together } \\
\text { from } 7 \text {. June to } 3 \text { July }\end{array}$} \\
\hline $\begin{array}{c}\text { No. of } \\
\text { females } \\
\text { laying eggs } \\
(\%)\end{array}$ & $\begin{array}{l}\text { No. of } \\
\text { eggs in the } \\
1^{\text {st }} \text { clutch } \\
(\%)\end{array}$ & $\begin{array}{l}\text { Average } \\
\text { no. of } \\
\text { eggs in the } \\
1^{\text {st }} \text { clutch } \\
\text { (min-max) }\end{array}$ & $\begin{array}{l}\text { No. of } \\
\text { females } \\
\text { in the } 2^{\text {nd }} \\
\text { clutch } \\
(\%)\end{array}$ & $\begin{array}{l}\text { No. of eggs } \\
\text { in the } 2^{\text {nd }} \\
\text { clutch }(\%)\end{array}$ & $\begin{array}{l}\text { Average } \\
\text { no. of } \\
\text { eggs in } \\
\text { the } 2^{\text {nd }} \\
\text { clutch } \\
\text { (min-max) }\end{array}$ & $\begin{array}{l}\text { No. of eggs } \\
\text { in both } \\
\text { clutches } \\
\text { according } \\
\text { to the first } \\
\text { year }(\%)\end{array}$ & $\begin{array}{l}\text { Average } \\
\text { no. of eggs } \\
\text { in both } \\
\text { clutches } \\
\text { (min-max) }\end{array}$ \\
\hline $4(100.0)$ & $14(82.4)$ & $3.5(2-5)$ & $1(25.0)$ & $3(17.6)$ & $3.0(3)$ & $17(10.2)$ & $3.4(2-5)$ \\
\hline
\end{tabular}

We established a yearly drop in the number of eggs from $76.0 \%$ to $24.0 \%$ and finally to $8.0 \%$ and a diminished number of clutches.

There was a small correlation found between animal weight and the number of eggs laid ( $\mathrm{rs}=0.312, \mathrm{p}=0.027, \mathrm{~N}=50$ ). On the other hand, no correlation was found between animal weight and egg weight $(\mathrm{rs}=0.124, \mathrm{p}=0.459, \mathrm{~N}=38)$. The correlation was calculated for only the first year. The samples in the second and third years were not large enough for statistical analysis. 
Table 2. Weight, length and width measurements of the eggs for each season.

\begin{tabular}{|c|c|c|c|c|c|}
\hline \multicolumn{6}{|c|}{ First year } \\
\hline $\begin{array}{l}\text { Weight of } \\
\text { eggs in grams } \\
\text { (min-max) }\end{array}$ & $\begin{array}{l}\text { Average } \\
\text { weight in } \\
\text { grams }\end{array}$ & $\begin{array}{l}\text { Length of eggs } \\
\text { in mm } \\
\text { (min-max) }\end{array}$ & $\begin{array}{l}\text { Average length } \\
\text { in } \mathrm{mm}\end{array}$ & $\begin{array}{l}\text { Width of eggs } \\
\text { in mm } \\
\text { (min-max) }\end{array}$ & $\begin{array}{l}\text { Average width } \\
\text { in } \mathrm{mm}\end{array}$ \\
\hline $10.2-21.0$ & 16.8 & $30.0-40.8$ & 36.1 & $23.3-31.0$ & 28.0 \\
\hline \multicolumn{6}{|c|}{ Second year } \\
\hline $\begin{array}{l}\text { Weight of } \\
\text { eggs in grams } \\
\text { (min-max) }\end{array}$ & $\begin{array}{l}\text { Average } \\
\text { weight in } \\
\text { grams }\end{array}$ & $\begin{array}{l}\text { Length of eggs } \\
\text { in mm } \\
\text { (min-max) }\end{array}$ & $\begin{array}{l}\text { Average length } \\
\text { in } \mathrm{mm}\end{array}$ & $\begin{array}{l}\text { Width of eggs } \\
\text { in mm } \\
\text { (min-max) }\end{array}$ & $\begin{array}{l}\text { Average width } \\
\text { in } \mathrm{mm}\end{array}$ \\
\hline $12.7-19.3$ & 15.1 & $31.6-37.3$ & 33.9 & $25.5-29.6$ & 27.5 \\
\hline \multicolumn{6}{|c|}{ Third year } \\
\hline $\begin{array}{l}\text { Weight of } \\
\text { eggs in grams } \\
\text { (min-max) }\end{array}$ & $\begin{array}{c}\text { Average } \\
\text { weight in } \\
\text { grams }\end{array}$ & $\begin{array}{c}\text { Length of eggs } \\
\text { in mm } \\
\text { (min-max) }\end{array}$ & $\begin{array}{l}\text { Average length } \\
\text { in } \mathrm{mm}\end{array}$ & $\begin{array}{c}\text { Width of eggs } \\
\text { in mm } \\
\text { (min-max) }\end{array}$ & $\begin{array}{l}\text { Average width } \\
\text { in } \mathrm{mm}\end{array}$ \\
\hline $12.3-17.4$ & 15.9 & $29.8-37.2$ & 34.6 & $25.5-29.8$ & 28.0 \\
\hline \multicolumn{6}{|c|}{ All three years together } \\
\hline $\begin{array}{l}\text { Weight of } \\
\text { eggs in grams } \\
\text { (min-max) }\end{array}$ & $\begin{array}{c}\text { Average } \\
\text { weight in } \\
\text { grams }\end{array}$ & $\begin{array}{c}\text { Length of eggs } \\
\text { in mm } \\
\text { (min-max) }\end{array}$ & $\begin{array}{l}\text { Average length } \\
\text { in } \mathrm{mm}\end{array}$ & $\begin{array}{c}\text { Width of eggs } \\
\text { in mm } \\
\text { (min-max) }\end{array}$ & $\begin{array}{l}\text { Average width } \\
\text { in } \mathrm{mm}\end{array}$ \\
\hline $10.2-21.0$ & 16.5 & $29.8-40.8$ & 35.6 & $23.3-31.0$ & 27.9 \\
\hline
\end{tabular}

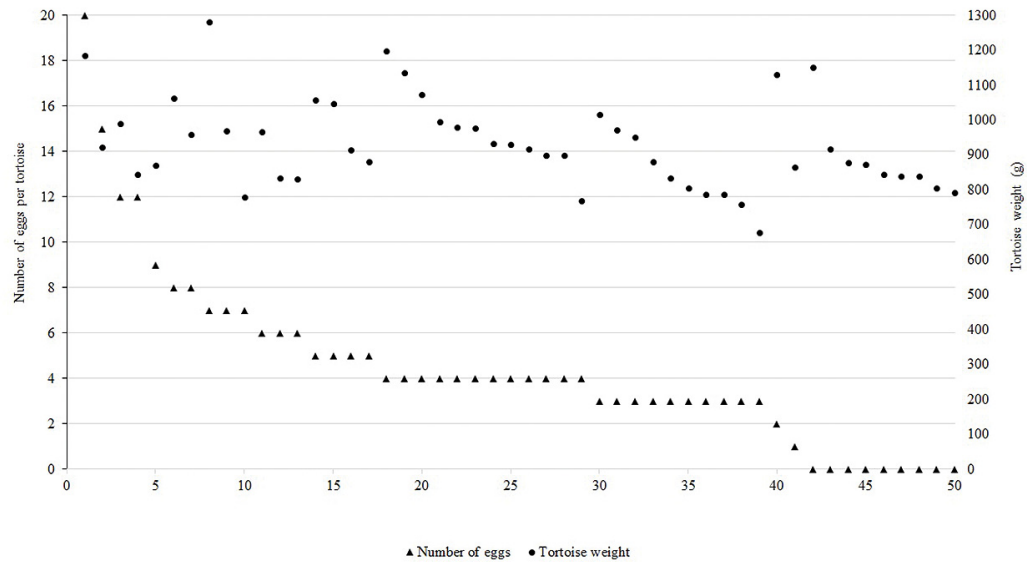

Graph 1. Comparison of the weight of a single tortoise and the number of eggs laid per clutch over a three-year period. There was a small but statistically significant correlation between the weight of the tortoises and the number of eggs laid $(r=0.312, p=0.027)$. 


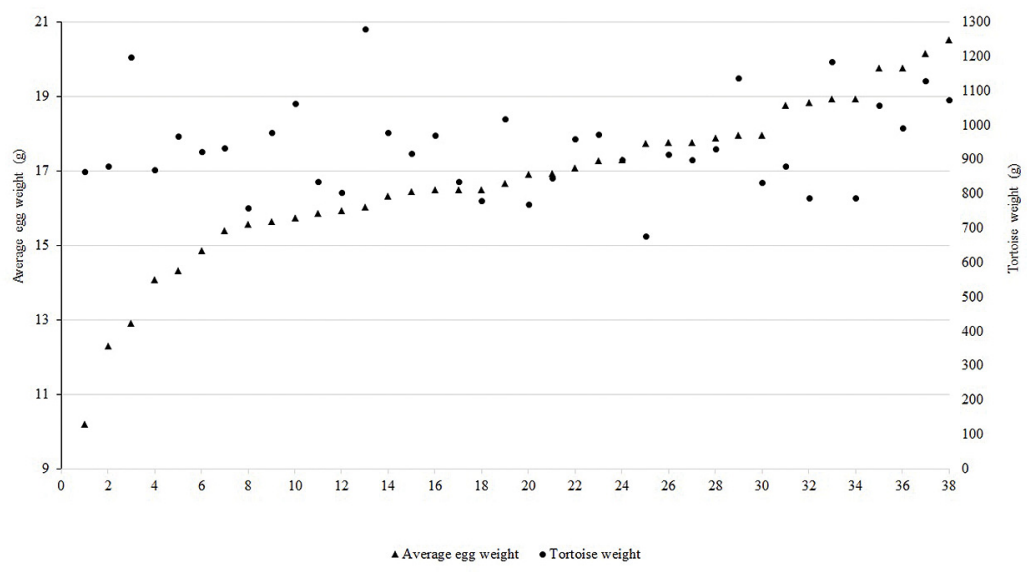

Graph 2. Comparison of the weight of the tortoise and its average egg weight in the first year. There was no significant correlation between the weight of the tortoises and the average weight of the eggs laid $(r=0.124, p=0.459)$.

\section{Artificial incubation and eggshell mortality}

In the first year, the average incubation length was 60.3 days; the length varied from 55 to 70 days. The viability rate for incubated eggs was $80.7 \%$ (134 eggs), and the eggshell mortality was 19.3\% (32 eggs). Out of all unhatched eggs, 20 eggs $(62.5 \%)$ were unfertilized, 17 (53.1\%) were infected, 9 (28.1\%) were dehydrated and $7(21.9 \%)$ were in various stages of embryonic development; one of them was still alive. The percentages overlapped because two or more causes were identified for some eggs. Within bacterial and mycological infections, Pseudomonas aeruginosa, Bacillus sp., and Purpureocillium lilacinum were the most common microbes isolated from infected eggs. All samples were negative for the pathogenic fungus Aspergillus. Regrettably, in some of the cases, the isolated bacteria and fungi remained undetermined. The fertilized eggs were further divided into three groups according to the stage of embryonic development. Embryos in the early stage of development were found in $9.38 \%$ (three embryos) fertilized eggs, and embryos in the middle and late stages were found in $6.25 \%$ (two embryos in each stage). In the late stage, one tortoise was still alive and was unable to peck through the shell. No individuals with deformities or twins were present.

In the second year, the average incubation length was 54.2 days; the length varied from 52 to 57 days. The viability rate for incubated eggs was 80.5\% (33 eggs). Eggshell mortality was $19.5 \%$ (8 eggs). Out of eight unhatched eggs, two were unfertilized and four were fertilized. In these four eggs, development was discontinued in the early stage. In two cases, the content had changed so much that it was impossible to determine whether fertilization occurred. 
In the third year, the average incubation length was 53.8 days, and the length varied from 53 to 57 days. The viability rate of the incubated eggs was $47.8 \%$ (8 eggs). Eggshell mortality was present in $52.2 \%$ of the cases (9 eggs). Out of nine unhatched eggs, seven were unfertilized and in two, development ended in the early stage. Among these seven eggs, three were infected, and four were dried.

Regular annual monitoring of the control enclosures of breeding tortoises, which located around the experimental group of females, showed that they were within normal, expected values.

The absence of males undoubtedly also affected the number of fertilized eggs in the incubator.

\section{DISCUSSION}

\section{Parent tortoises}

Pearse et al. (2001) proved that fertility decreases significantly after each season, although sperm remains viable in the female genital tract for as long as three to four years [16]. Cutuli et al. (2013) described the reason for this phenomenon. Chelonian species present one of the best examples of long-term sperm storage. Sperm storage tubules are located in the posterior portion of the albumin-secreting region of the oviduct [6]. In our study, the impact of male absence on the number of eggs laid and the number of clutches was examined. In the group of fifty Hermann's tortoises (Testudo hermanni), the number of eggs and clutches were monitored during the threeyear period. The number of eggs in the second year and third year decreased to $24.7 \%$ and $10.2 \%$, respectively, of that in the first year $(100 \%)$.

Bjorndal and Carr [17] compared the masses and ages of turtles with the number and mass of laid eggs in green turtles (Chelonia mydas). They found that female body size was significantly correlated with clutch size, but at the population level, it increased significantly throughout the nesting season. At the individual level, the increase in clutch size was not significant but increased significantly with the age of the female. The increase in body size with age was not significant. They also found that egg size was significantly correlated with female body size.

In Hermann's tortoises, no similar studies have been performed. Three years of male absence were studied with this group of 50 females to assess the parameters of clutching and hatching for the first time. In the first year of our study, we compared the mass of turtles with the number and mass of hatched eggs. A small but significant correlation between the body size of the tortoise and the number of eggs was found.

Bertolero et al. (2011) mentioned a maximum of nine eggs in THB and one or two and rarely three clutches per season. We have never recorded more than seven eggs or found a third clutch. The absence of males affected the number of clutching eggs per tortoise and the number of first and second clutches. 
In our study, the average size of the THB eggs was lower than that measured in 2017 [18]. The results of the average measurements were $27.9 \times 35.6 \mathrm{~mm}$ for width and length, and the average weight was $16.5 \mathrm{~g}$. Differences among the weights of tortoises and the number of eggs per clutch could correlate with diet and health status. Bertolero et al. (2011) obtained a slightly lower average value than Stvarnik et al. (2017). THB egg size measurements were $27.9 \times 37.4 \mathrm{~mm}$ and weighed $17.1 \mathrm{~g}$ [1]. The average size of THB egg measurements was $29.9 \times 39.5 \mathrm{~mm}$, the average weight was $20.7 \mathrm{~g}$ [18]. The THB eggs that were measured by Highfield (1996) were larger but lighter: they were $40 \times 29 \mathrm{~mm}$ and weighed 12 to $14 \mathrm{~g}[1,19]$. Hailey and Loumbourdis (1988) established that the average egg weight for THB was $17.8 \mathrm{~g}$, ranging from 10.5 to 23.5 g [20].

\section{Egg collection and artificial incubation}

The incubation times range from 90 to 124 days in the wild and from 56 to 102 days under artificial conditions within the temperature range from 22 to $35^{\circ} \mathrm{C}$ [7]. Eendebak (2001) recorded incubation periods from 88.3 to 109.2 days at a given incubation temperature (from 24 to $36^{\circ} \mathrm{C}$ ) [11]. In our artificial incubation, all eggs were kept under the same microhabitat conditions. The hatching time varied from 52 to 70 days at temperatures of 31 to $32^{\circ} \mathrm{C}$ and $80 \%$ humidity, which do not align with the metrics of other authors. We obtained slightly lower values, especially in the second and third years of tracking, when the incubation period ranged from 52 to 57 days. Our results were most similar to those of Eendebak (2001), who found that incubation lasted from 55.3 to 57.4 days at temperatures from 31 to $32^{\circ} \mathrm{C}$ [11].

The health status and food consumption of the parent group, male and female ratio, and microclimatic conditions (temperature, relative humidity) throughout incubation are important factors for viability [14]. Some authors [21,22] have found that fertilized eggs are larger than unfertilized eggs. The results of our study confirmed these findings. Among 125 eggs (others were destroyed and not included in the calculation), fertilized eggs were $0.9 \mathrm{~g}$ heavier than unfertilized eggs. The main reason was probably that the larger eggs were less susceptible to the negative effects of environmental factors than the smaller eggs. Our strategy and suggestions are to maintain regular control, to conduct regular examination of the eggs and to eliminate all eggs under 10 $\mathrm{g}$ and eggs with misshapen or broken shells.

The data in the professional literature about embryonic development in reptiles are poor and describe other turtle species [12,13] but not Hermann's tortoises.

In our previous publication, [14] embryonic mortality was $14.9 \%$ and was divided into different stages: $2.2 \%$ occurred in the early stage of development, $5.2 \%$ in the middle stage and $7.5 \%$ in the late stage. In the present study, we noticed a higher percentage of embryonic deaths in the early stage of development. Dead embryos were found in $9.38 \%$ of eggs in the early stage of development and $6.25 \%$ in the middle and late stages (two embryos in each). A high percentage of dehydrated eggs 
$(28.1 \%)$ was also noticed. The reason for high embryonic deaths in the early stage and high percentages of dehydrated eggs could be a failure in environmental factors, such as high temperature or low relative humidity. During incubation, the monitoring of microclimatic indicators, such as temperature and relative humidity, is therefore strongly recommended, and an alarm device must be utilized.

For good reproduction on turtle farms, sexually active males and females must always be present. Special considerations should be given to reducing the percentage of females that do not clutch. In the first year of the present study, $24.0 \%$ females did not produce eggs even though the ratio of males versus females was 1:4.2. The health status and food consumption of the females and males, their ratio, and appropriate hibernation need to be followed regularly. Reproductive diseases, chronic infections and/or invasions with different pathogens and metabolic diseases have an important role and should be controlled. Therefore, regular monitoring is recommended to maintain their health, especially to help ensure and improve their welfare.

It is necessary to regularly record total egg failure and improve the hatching conditions to obtain healthy offspring. Due to improper hatching, many weak individuals can die in infancy or can suffer health problems. Some parameters have to be monitored and changes implemented according to the measurements. The eggs should be lit using a bright light prior to incubation and periodically during incubation to promptly assess and eliminate all unfertilized eggs or dead embryos. Fumigation with disinfectants prior to incubation is necessary. It is important to establish appropriate temperature and relative humidity, incubate only "clean" eggs and maintain healthy parent groups of tortoises. Improving the hatching conditions, reducing the risk of infections, and increasing the percentage of hatching and the welfare of tortoises in general are crucial.

\section{CONCLUSIONS}

The weight of a tortoise has a low influence on the number of eggs but no influence on the weight of eggs. We showed that the absence of males had an impact on different parameters in reproduction and artificial incubation outcomes. It impacted the drop in the number of eggs and clutches. Each year, the viability rate of the incubated eggs was lower. The absence of males also affected the number of fertilized eggs in the incubator.

\section{Authors' contributions}

MJ carried out the microbiological studies. SM, GGG, DA, LKR and $\check{\text { Š }}$ participated in the design of the study, carried out the eggshell mortality and performed the statistical analysis. SM and DA conceived of the study and participated in its design and coordination and helped to draft the manuscript. All authors read and approved the final manuscript. 


\section{Declaration of conflicting interests}

The author(s) declared no potential conflicts of interest with respect to the research, authorship, and/or publication of this article.

\section{Acknowledgements}

The authors would like to thank the breeder of the tortoises for all cooperation in this study. According to the national legislation, the breeder obtained the breeding permit for breeding of Hermann's tortoises, which was No. 35601-182/2010, dated 11th January 2011, and was issued by the Ministry for the Environment and Spatial Planning.

\section{REFERENCES}

1. Bertolero A, Cheylan M, Hailey A, Livoreil B, Willemsen RE: Testudo hermanni (Gmelin 1789) - Hermann's tortoise. In Conservation biology of freshwater turtles and tortoises: A compilation project of the IUCN/SSC tortoise and freshwater turtle specialist group Chelonian research monographs. Edited by Rhodin AGJ, Pritchard PCH, van Dijk PP, Saumure RA, Buhlmann KA, Iverson JB, Mittermeier RA; 2011: 059.051-059.020

2. Fritz U, Auer M, Bertolero A, Cheylan M, Fattizzo T, Hundsdörfer AK, Sampayo MM, Pretus JL, Široky P, Wink M: A rangewide phylogeography of Hermann's tortoise, Testudo hermanni (Reptilia: Testudines: Testudinidae): implications for taxonomy. Zool Scripta 2006, 35:531-543.

3. Dovč A, Račnik J, Zorman Rojs O, Lindtner-Knific R, Krapež U, Mavri U, Arih A, Vlahović A: Reja grških želv v Sloveniji. Vet Nov 2005, 31:173-183.

4. Willemsen RE: Status of Testudo hermanni in Greece. In Red data book on Mediterranean chelonians. Edited by Ballasian D. Bologna, Italy: Edagricole - Edizioni Agricoli; 1995: 110118

5. Stubbs D: Testudo hermanni, Hermann's Tortoise. In The Conservation Biology of Tortoises. Edited by Swingland IR, Klemens MW. Gland, Switzerland; 1989: pp. 34-36.[IUCN (Series Editor)

6. Cutuli G, Cannicci S, Vannini M, Fratini S: Influence of mating order on courtship displays and stored sperm utilization in Hermann's tortoises (Testudo hermanni hermanni). Behav Ecol Sociobiol 2013, 56: 273-281.

7. Gvozdenović S, Iković V: Egg incubation period in the Hermann's tortoise Testudo hermanni Gmelin, 1789 (Testudines, Cryptodira, Testudinidae). Hyla 2014, 2:45-46.

8. Swingland IR, Stubbs D: The ecology of a Mediterranean tortoise (Testudo hermanni): Reproduction. Journal of Zoology 2009, 205:595 - 610.

9. Galeotti P, Sacchi R, Pellitteri-Rosa D, Fasola M: Olfactory Discrimination of Species, Sex, and Sexual Maturity by the Hermann's Tortoise Testudo Hermanni. Coperia 2007, 4.

10. Ferguson MWJ, Deeming DC: Egg incubation: its effects on embryonic development in birds and reptiles. Cambridge: Cambridge University Press; 1991.

11. Eendebak B: Incubation period and sex ratio of Testudo hermanni boettgeri. In International Congress on Testudo Genus; march 7-10, 2001; Gonfaron-Hyères-France. 2001

12. Tokita M, Kuratani S: Normal Embryonic Stages of the Chinese Softshelled Turtle Pelodiscus sinensis (Trionychidae). Zoological Science 2001, 18:705-715. 
13. Crastz F: Embryological stages of the marine turtle Lepidochelys olivacea (Eschscholtz). Revista de biologia tropical 1982, 30(2):113-120.

14. Stvarnik M, Klobučar I, Lindtner Knific R, Gregurić Gračner G, Dovč A: Hatching artefacts in Hermann's tortoise (Testudo hermanni) after artificial incubation. Clinical theriogenology 2019, 11:479.

15. Dovč A, Stvarnik M, Mavri U, Gregurić-Gračner G, I. T: Experiences with Hermann's tortoise (Testudo hermanni) microchipping in Slovenia - short communication. Acta Vet Hung 2016, 64:47-53.

16. Pearse DE, Janzen FJ, Avise JC: Genetic markers substantiate long-term storage and utilization of sperm by female painted turtles. Heredity 2001, 86:378-384.

17. Bjorndal KA, Carr A: Variation in Clutch Size and Egg Size in the Green Turtle Nesting Population at Tortuguero, Costa-Rica. Herpetologica 1989, 45:181-189.

18. Stvarnik M, Bajc Z, Gačnik KS, Dovč A: Evaluation of different chemical compositions in eggs of the Hermann's tortoise (Testudo hermanni). Slovenian Veterinary Research 2017, 54:1120.

19. Highfield AC: Practical captive breeding and species maintenance profiles. Part II. In Practical encyclopedia of keeping and breeding tortoises and freshwater turtles. Volume Vii. $1^{\text {st }}$ edition. Edited by Highfield AC. London, England: Carapace Press; 1996: 141-257.

20. Hailey A, Loumbourdis NS: Egg size and shape, clutch dynamics, and reproductive effort in European tortoises. Can J Zool 1988, 66:1527-1536.

21. Noel KM, Qualls CP, Ennen JR: A Comparison of Artificial Incubation and Natural Incubation Hatching Success of Gopher Tortoise $(<\mathrm{i}>$ Gopherus polyphemus $</ \mathrm{i}>$ ) Eggs In Southern Mississippi. Herpetologica 2012, 68:324-333, 310.

22. Landers JL, Garner JA, Mcrae WA: Reproduction of Gopher Tortoises (GopherusPolyphemus) in Southwestern Georgia. Herpetologica 1980, 36:353-361.

\title{
PRAĆENJE NOSIVOSTI JAJA ŠUMSKE KORNJAČE (TESTUDO HERMANNI) BEZ PRISUSTVA MUŽJAKA KAO I MORTALITET JAJA NA VELIKOJ FARMI KORNJAČA U SLOVENIJI TOKOM TROGODIŠNJEG PERIODA
}

\author{
STVARNIK Mateja, LINDTNER-KNIFIC Renata, ŠTOKAR Žan, \\ GREGURIĆ GRAČNER Gordana, MIĆUNOVIĆ Jasna, DOVČ Alenka
}

Cilj studije je bio da se odredi procenat nosivosti i fertilizacija jaja kod ženki šumske kornjače, pre i posle uklanjanja mužjaka nakon parenja. Grupa koja je ispitivana, obuhvatala je 50 ženki i 12 mužjaka Testudo hermanni boettgeri kornjača. U toku prve godine, sve su životinje bile smeštene $\mathrm{u}$ isti habitat sve do pojave reproduktivne aktivnosti. $\mathrm{Na}$ kraju meseca maja, ženke i mužjaci su odvojeni u toku dve aktivne sezone. Broj jaja i broj drugog poleganja jaja, opadao je postepeno. U toku prve godine, 76,0\% ženki je položilo jaja; tokom druge godine, $24,0 \%$, a tokom treće godine, samo $8,0 \%$. Drugo 
nošenje jaja je uočeno kod deset ženki (26,3\%) tokom prve godine, pri čemu je tokom naredne dve godine, jedna ženka položila jaja po drugi put. Postojala je mala, ali značajna korelacija između telesne mase svake pojedinačne životinje i broja jaja, međutim, nije postojala značajna korelacija između telesne mase svake pojedinačne životinje $i$ prosečne mase (težine) jaja. Obavljeno je i merenje težine (15,1 do 16,8 gr), dužine $(33,9$ do $36,1 \mathrm{~mm})$ i širine $(27,5$ i $28,9 \mathrm{~mm})$ jaja.

Tokom sezone nošenja, jaja su stavljana u inkubatore. Dužina perioda inkubiraja jaja je varirala i iznosila je od 52 do 70 dana. Posle završene inkubacije, mortalitet jaja kao i uzroci mortaliteta (19,3 do 52,5\%) bili su ispitivani. Tokom prve godine, stepen vijabilnosti inkubiranih jaja bio je $80,7 \%$; tokom druge godine $80,5 \%$ i u trećoj godini $47,8 \%$. Od ukupnog broja jaja tokom prve godine, $62,5 \%$ nisu bila oplođena, $52,1 \%$ jaja je bilo inficirano, $28,1 \%$ je bilo dehidrirano i $21.9 \%$ jaja je pronađeno u različitim stadijumima razvoja embriona. 